Volume:8 Issue:1

https://dx.doi.org/10.19128/turje.449100
Turkish Journal of

Education

Research Article

www.turje.org

\begin{tabular}{c|c} 
Received & 30.07 .2018 \\
\hline Accepted & 08.01 .2019
\end{tabular}

\title{
Facilitating grade 11 students' conceptual understanding of fundamental acid-base models
}

\author{
Fatma Yaman \\ Yozgat Bozok University, Faculty of Education, Department of Science and Mathematics Education, Yozgat, \\ Turkey, fatmayaman@ymail.com \\ ORCID: https://orcid.org/0000-0002-4014-3028
}

Alipaşa Ayas

Bilkent University, Faculty of Education, Department of Curriculum and Instruction, Ankara, Turkey, alipasaayas@yahoo.com

ORCID: https://orcid.org/0000-0002-4898-2918

Muammer Çalık

Trabzon University, Faculty of Fatih Education, Department of Elementary Teacher Education, Trabzon,

Turkey, muammer38@ hotmail.com

ORCID: https://orcid.org/0000-0001-8323-8783

\begin{abstract}
The purpose of this study was to enhance grade 11 students' conceptual understanding of fundamental acid-base models using Predict-Observe-Explain based animated movies (POE-AM). Twelve grade 11 students participated in the study. To collect data, the students' responses to the POE-AM tasks and interview protocols were used. The findings indicated that the POE-AM tasks positively improved the students' conceptual understanding of fundamental acid-base models and remedied any deficiency identified in pre-interviews and/or the 'predict' stage of the POE strategy. The results also showed that before implementation the students stated the main parts of acids and bases as $\mathrm{H}^{+}$and $\mathrm{OH}^{-}$ions, respectively. After the implementation, they indicated that the Arrhenius model had the least adequate explanation to imply features/behaviors of acids and bases whilst the Lewis model did the most adequate acid-base definition to address their features/behaviors. Moreover, the study revealed that most of the students had alternative understanding or only partial understanding at the 'predict', but showed somewhat a sound understanding of these concepts at the 'observe' and 'explain' stages. The current study suggests that chemistry teachers should integrate the POE-AM into their classes to effectively promote student learning.
\end{abstract}

Keywords: Acid-base models, Conceptual understanding, POE-based animated movies

\section{Sınıf öğrencilerinin temel asit-baz modelleriyle ilgili kavramsal anlamalarını kolaylaştırma}

ÖZ Bu çalışma, 11. sınıf öğrencilerinin temel asit-baz modelleriyle ilgili kavramsal anlamalarını TahminGözlem-Açıklama temelli animasyon filmleriyle (TGA-AF) artırmayı amaçlamaktadır. Çalışmaya 12 onbirinci sınıf öğrencisi katılmıştır. Veri toplamak için öğrencilerin TGA-AF etkinliklerine ve mülakat protokollerine verdikleri cevaplar kullanılmıştır. Elde edilen bulgular, TGA-AF etkinliklerinin öğrencilerin temel asit-baz modelleriyle ilgili kavramsal anlamalarını pozitif olarak geliştirdiğini ve ön mülakatlarda ve/veya TGA stratejisinin tahmin aşamasında belirlenen eksiklikleri giderdiğini göstermiştir. Öğrenciler uygulamadan önce asit ve bazların temel bölümlerinin sırasıyla $\mathrm{H}^{+}$ve $\mathrm{OH}^{-}$ iyonları olduğunu ifade etmiştir. Uygulamadan sonra ise öğrenciler asit ve bazların özelliklerini ve davranışlarını açıklamak için Arrhenius modelinin en az ve Lewis modelinin ise en çok yeterli açıklamaya sahip olduğunu belirtmişlerdir. Ayrıca, öğrencilerin çoğunluğunun TGA'nın "tahmin" aşamasında alternatif ya da kısmi anlamaya sahip olduğu; ancak, "gözlem" ve "açıklama" aşamalarında belli bir dereceye kadar tam anlamayı gösterdikleri ortaya çıkmışır. Bu çalışma, kimya öğretmenlerinin öğrencinin öğrenmesini etkili olarak teşvik etmek için TGA-AF'yi kendi sınıflarına entegre etmelerini önermektedir.

Anahtar Kelimeler:

Asit-baz modelleri, Kavramsal anlama, TGA temelli animasyon filmleri

Cite This

Yaman, F., Ayas, A. \& Çalık M., (2019). Facilitating grade 11 students' conceptual

Article: understanding of fundamental acid-base models, Turkish Journal of Education. 8(1), 16-32. https://dx.doi.org/10.19128/turje.449100 


\section{INTRODUCTION}

Studies in science education have emphasized that knowing students' pre-conceptions is a pre-requisite for improving student learning in science classes (Coştu, Ayas \& Niaz, 2012; Liew, 1995; Kearney, 2004). The constructivist view of learning suggests that pre-existing knowledge affects students' subsequent learning. Therefore, it is crucial to probe students' understanding of science concepts to properly organize subsequent advanced learning (Kearney \& Treagust, 2001). There have been a number of approaches to investigate students' understanding of science concepts (White \& Gunstone, 1992) such as concept mapping (Novak\& Gowin, 1984), Predict-Observe-Explain (POE) (Kearney, 2004; Kearney \& Treagust, 2001; Liew, 1995; Liew \& Treagust,1998), interviews about instances (Osborne \& Cosgrove, 1983), interviews about concepts (Abdullah \& Scaife, 1997), drawings (Smith \& Metz, 1996), and word association tests (Bahar \& Tongaç, 2009). A POE strategy identifies students' understanding of science concepts and promotes student discussion in the learning process (Kearney \& Treagust, 2001; Liew \& Treagust, 1998). In the POE strategy, students predict the outcome of an event or situation, and indicate the reasons for their predictions. Then, they observe the event or situation, and explain any discrepancy between their predictions and observations (Kearney \& Treagust, 2001; Liew \& Treagust, 1998; White \& Gunstone, 1992).

Although a few studies have sparingly used computer-based POE tasks (Acar-Şeşen, 2013; Kearney, 2004; Kearney \& Treagust, 2001; Kearney, Treagust, Shelley \& Zadnik, 2001), none of them have employed animated movies in the POE tasks. Kearney, Treagust, Shelley, and Zadnik (2001) investigated high school students' and their teachers' perceptions of the effectiveness of computer-based POE tasks in probing the students' conceptions and promoting students' discussions. They argued that the computer-based POE tasks gave the students an opportunity to control the POE stages. Moreover, the tasks enabled them to effectively use their learning times and to enhance their self-confidence levels to discuss their views of the phenomena. Kearney (2004) also investigated the effects of collaborative use of multimedia-based POE tasks on students' pre-conceptions and peer learning. Kearney (2004) stated that the tasks supported peer learning conversations at every stage of the POE strategy, except for the explanation stage. Moreover, Kearney and Treagust (2001) reported that computer-based POE tasks provided a rich discussion/conversation environment for high school students at every stage of the POE strategy.

Given the foregoing advantages of the POE strategy, the related literature suggests that the POE tasks are effective tools in identifying students' misconceptions (Champagne, Klopher \& Anderson, 1980), pre-conceptions (Acar-Şeşen, 2013; Kearney, 2004; Kearney \& Treagust, 2001; Kearney, Treagust, Shelley \& Zadnik, 2001), and achieving conceptual change (Çalık \& Cobern, 2017; Tao \& Gunstone, 1999). In a parallel with the POE strategy, studies in science education deploy simulations and animations for describing, explaining, and predicting the scientific process/phenomenon. Further, animated movies can show scientific phenomena occurring at the sub-microscopic (i.e., molecules and atoms) or macroscopic level (e.g., acid-base indicator colors) (Barak, Ashkar \& Dori, 2011; Nahleh \& Krajcik, 1994). The use of animated movies in science classes has positive effects on 4th and 5th grade students' learning motivation, conceptual understanding and thinking skills of "motion and forces, the life on earth, environmental issues" topics (Barak, Ashkar \& Dori, 2011). Hence, given the advantages of the POE tasks and animated movies, the present study intended to combine them within an enriched learning environment (as a POE-based animated movies) increasing students' conceptual understanding.

Because conceptual understanding plays an important role in achieving further learning and evolving students' interests/attitudes towards science/chemistry (i.e., Çalık, Ayas \& Coll, 2009; Er Nas, Calik \& Cepni, 2012; Kiryak \& Çalik, 2018), much more studies have concentrated on students' conceptual understanding and difficulties of various chemistry topics (e.g., gases, electrochemistry, acids and bases). Earlier studies of fundamental acid-base models have shown that students have several 
difficulties in understanding the acid-base chemistry and related models. For instance; Cartrette and Mayo (2011) reported that students tended to exploit the Bronsted-Lowry model in defining acids and bases, while they were unable to correctly use the Lewis model. Similarly, Tümay (2016) addressed that students predominantly employed the Arrhenius model to describe acids and bases. Further, Artdej, Ratanaroutai, Coll and Thongpanchang (2011) indicated that students had difficulties in differentiating the Arrhenius and Bronsted-Lowry models from each other. Carr (1984) pointed out that the Arrhenius and Bronsted-Lowry models were not clearly distinguished in university and high school textbooks. Therefore, Carr (1984) stated that students tended to interchangeably exploit these models. Hawkes (1992) reported that students found the Arrhenius model problematic. He suggests that the BronstedLowry model, which is more basic than the Arrhenius model, should firstly be taught. Hawkes (1992) claimed that the Bronsted-Lowry model describing the proton transfer might not lead to any misunderstanding. Similarly, if acids and bases are associated with $\mathrm{HAn}\left(\mathrm{An}=\mathrm{Cl}^{-}, \mathrm{NO}_{3}{ }^{-}\right.$etc. $)$and $\mathrm{MOH}$ $\left(\mathrm{M}=\mathrm{Na}^{+}, \mathrm{K}^{+}\right.$etc.) respectively, students may have no problems in comprehending the definitions provided by the Bronsted-Lowry model (Zoller, 1990).

In contrast, many students have difficulties in understanding the Lewis model because of such concepts as acidity, basicity, electrophilicity, and nucleophilicity. Shapperd (1997) pointed out that, even after completing general acid-base courses, high school students were unable to distinguish the acid-base models from each other. Drechsler and Schmidt (2005a) reported that students addressed the acid-base reactions at the macroscopic level, but they could not explicate them correctly at the sub-microscopic level. Further, even though students agreed that chemistry dealt with these models/levels, they did not realize why they needed several models/levels to explain the acid-base reactions (Drechsler and Schmidt, 2005). Similarly, Justi and Gilbert (2002) and Drechsler and Schmidt (2005b) implied that teachers did not effectively use different acid-base models in their classes. Also, Drechsler and Schmidt (2005b), who analyzed chemistry textbooks, found that neither the textbooks nor the teachers clarified the existence of different acid-base models. Kousathana et al. (2005) depicted that even though most of the students identified the Bronsted-Lowry model, they were unable to provide the correct explanations. Moreover, they pointed out that students were more familiar with the Arrhenius model. Tarhan and Acar Sesen $(2008,2012)$ found that students had deficiencies in explaining electron transfer of the Lewis model, basicity of any substance (without $\mathrm{OH}^{-}$ions), and differences between $\mathrm{H}^{+}$ions and protons. Furthermore, they implied that students preferred the Bronsted-Lowry model to define acids and bases. In summary, the foregoing studies have indicated students' difficulties and alternative conceptions of the acid-base models.

\section{Purpose of the Study}

The main purpose of this study was to enhance grade 11 students' conceptual understanding of the fundamental acid-base models using animated movies embedded within a Predict-Observe-Explain (POE) strategy. For this purpose, the following research questions guided the present study:

1) What are grade 11 students' understanding levels of the fundamental acid-base models before and after the teaching intervention?

2) How do grade 11 students' understanding levels change after the teaching intervention?

\section{METHODOLOGY}

This study used the embedded design of mixed method combining qualitative data collection and analysis with a traditional quantitative research design (Creswell \& Plano Clark, 2011). The embedded design suggests to collect and analyze the data before, during, and/or after the implementation (Creswell 
\& Plano Clark, 2011). For the current study, the authors set up a pre-experimental research design to examine the effect of the POE-AM tasks on grade 11 students' conceptual understanding, and deployed qualitative data collection instruments before (i.e., pre-interviews), during (i.e., students' responses to the POE tasks) and after (e.g., post-interviews) the teaching intervention.

\section{Participants of the Study}

The participants of this study were twelve grade 11 students (10 females and 2 males; aged 16-17 years) purposefully selected from one class. They represented below average, average and above average levels of achievement, which were determined via chemistry teacher's comments and their grades in previous chemistry courses. Because a typical purposeful sampling procedure (Merriam, 2009; Patton, 2002) refers to a person or makes unfamiliar situation "typical" (Merriam, 2009), the authors selected this type of sampling to reflect the average person, situation, or instance of the phenomenon under investigation. All participants voluntarily took part in the study. They were enrolled to an Anatolian high school on the northeast coast of Turkey and followed science track of the high school. They were very similar to each other (i.e., socio-economic status, income levels).

\section{The Context of the Study}

The Head Council of Education and Morality centrally prescribes all curricula in Turkey. Science at the primary school level involves three hours weekly in Grades 3 and 4, taught by primary school teachers. Science courses at the lower secondary education are taught by subject specialist teachers. Science is awarded four hours weekly in Grades 5 to 8 for the mandatory curricular components. Grade 9 science education includes three separate courses (biology, chemistry and physics) that are instructed by subjectspecialist teachers. After Grade 9 in the upper secondary education, students study packages of subjects depending on their track (science-intensive, social science-intensive, or a more general programme incorporating both). The students in the science-intensive track mainly attend such courses as Mathematics, Geometry, Physics, Chemistry and Biology. Teaching hours for science courses (Chemistry, Biology and Physics) range from two hours to four hours per week given the type of school.

Students firstly encounter acids and bases in grade 8 (aged 13-14 years) in Science course (Ministry of Education-MONE, 2013a). Grade 9 students are introduced to basic ideas about acids and bases in the "acids, bases and salts" unit. All acid-base definitions in grade 9 deal with the Arrhenius model without explicitly mentioning its name (MONE, 2013b) Grade 11 students are deeply taught advanced acid-base concepts in units "chemical calculations and rate of reaction". Also, the Arrhenius, Bronsted-Lowry and Lewis models are explicitly instructed in grade 11 (MONE, 2013b).

\section{Data Collection}

Students' written responses to the POE-based Animated Movies (POE-AM) tasks and interviews were used to collect data. Their written responses to the POE-AM tasks were gathered during the teaching intervention. Moreover, the authors prepared the interview questions by taking related literature and three chemistry educators' views into consideration. Also, the interview questions were pilot-tested with twelve grade 12 students, who had attended the fundamental acid-base models at grade 11 . Hence, the pilot-study ensured the validity and reliability of the interview questions. Further, the interviews were carried out before and after the teaching intervention. Each individual interview session lasted about 1015 minutes. Later, all interviews were audio-taped and transcribed. Pre-interviews aimed to investigate the students' pre-conceptions of the acid-base models before the teaching intervention. In a similar vein, post-interviews purposed to explore at which degree the students used the acid-base models after the teaching intervention. For this purpose, pre-interviews asked the following questions; "What do you think about the main part of an acid?" and "What do you think about the main part of a base?" Postinterviews required the students to respond the subsequent questions; "In your opinion, which of the acid-base models provides the best explanation to address features / behaviors of acids and bases?" and "In your opinion, which of the acid-base models has the least adequate explanation to imply 
features/behaviors of acids and bases?" Because using assessments of content directly aligned with the enacted curriculum may result in higher post-test scores or better explanations (Abraham, Grzybowski, Renner \& Marek, 1992; Çalık et al. 2014), the current study preferred exploiting the underlying acidbase questions in pre- and post-interviews without directly aligning with the curriculum.

\section{Procedure}

Within the embedded design of mixed method, the POE-AM tasks on acid-base models were used as a part of the regular chemistry curriculum. The students were interviewed prior to the instruction, and then studied on the POE-AM tasks during regular classroom hours. Each POE-AM task took two class-hours $(2 * 45$ minutes). At the end of the teaching intervention, the students were exposed to post-interviews. Thus, the students' responses to the POE-AM tasks (see questions in Table 1) were handled to evaluate their conceptual growth and/or understanding.

Three POE-AM tasks were underpinned with three fundamental acid-base models suggested by grade 11 chemistry curriculum. In the development of the POE-AM tasks, the narratives were initially prepared, and then embedded into the POE strategy. A voiceover was created for the animated movies.

All POE-AM task firstly required the students to watch the general part of the story of each acid-base model, then to predict what would happen in the next section of the animated movies, and finally to write their predictions and reasons. As soon as they completed their responses to the 'predict' stage, they continued to watch the animated movies and wrote down their observations. In the 'explain' stage, they were asked to put down whether there was any discrepancy between their predictions and observations. At the beginning of each task, student worksheets were handed out. At the end of each task, they were collected to give feedbacks and analyze their written responses. The students individually worked with the animated movies and observed the Arrheniuss, Bronsted-Lowry and Lewis acid-base models respectively (see Table 1).

In the first task (Arhenius acid-base model), the students watched the story of such substances as $\mathrm{NaOH}$, $\mathrm{Ba}(\mathrm{OH})_{2}, \mathrm{SO}_{2}, \mathrm{CO}_{2}, \mathrm{CH}_{3} \mathrm{COOH}, \mathrm{HCl}, \mathrm{NH}_{3}$. Then, the questions "In your opinion, which of the foregoing substances are the Arrhenius acids or bases?" and "Do you think if there is any reaction between the acid and base?" were asked to them. Later, they wrote their predictions and reasons to the student worksheets. Afterwards, they observed the rest of the story including the acid-base definitions, similar characteristics of the acids and bases (donating $\mathrm{H}^{+}$ions and $\mathrm{OH}^{-}$ions when dissolving in water), the limits of the Arrhenius model, and the chemical equation on the dissolution of an acid or base into water. Later, they put their observations down on the student worksheets. Finally, they were asked to depict any consistency or inconsistency between their predictions and observations and explain their reasons. The same teaching procedure was also followed for the Bronsted-Lowry and Lewis models respectively (see Table 1).

Table 1

An outline of the POE-AM tasks in the current study

\begin{tabular}{|c|c|c|c|}
\hline $\begin{array}{l}\text { POE-AM } \\
\text { Tasks }\end{array}$ & PREDICT & OBSERVE & EXPLAIN \\
\hline $\begin{array}{l}\text { The } \\
\text { Arrhenius } \\
\text { model } \\
\text { (Task 1) }\end{array}$ & $\begin{array}{l}\text { Requested the students to watch a story } \\
\text { related to behaviors of such substances } \\
\text { as } \mathrm{NaOH}, \mathrm{Ba}(\mathrm{OH})_{2}, \mathrm{SO}_{2}, \mathrm{CO}_{2} \text {, } \\
\mathrm{CH}_{3} \mathrm{COOH}, \mathrm{HCl}, \mathrm{NH}_{3} \text {. Then, they were } \\
\text { asked to respond the following } \\
\text { questions: "In your opinion, which of } \\
\text { the foregoing substances are the } \\
\text { Arrhenius acids or bases? Do you think } \\
\text { if there is any reaction between the acid } \\
\text { and base? Please write your prediction } \\
\text { and explain your reason(s)". }\end{array}$ & $\begin{array}{l}\text { Required them to watch the next } \\
\text { section of the animated movies to } \\
\text { observe the acid-base definitions; } \\
\text { similar characteristics of acids and } \\
\text { bases (donating } \mathrm{H}^{+} \text {ions and } \mathrm{OH}^{-} \text {ions } \\
\text { when dissolving in water); the limits } \\
\text { of the Arrhenius model; and the } \\
\text { chemical equation on the dissolution } \\
\text { of an acid or base into water. Later, } \\
\text { they put their observations down on } \\
\text { the worksheet. }\end{array}$ & $\begin{array}{l}\text { Asked to respond the } \\
\text { following questions: } \\
\text { Is there any } \\
\text { discrepancy between } \\
\text { your prediction and } \\
\text { observation? Please } \\
\text { state your reason(s). }\end{array}$ \\
\hline
\end{tabular}




\begin{tabular}{|c|c|c|}
\hline $\begin{array}{l}\text { The } \\
\text { Bronsted- } \\
\text { Lowry } \\
\text { model } \\
\text { (Task 2) }\end{array}$ & $\begin{array}{l}\text { Called them to watch the animated } \\
\text { movies on how Lowry and Bronsted } \\
\text { found the acidity and alkalinity } \\
\text { definitions of certain substances. Then, } \\
\text { they were required to state their } \\
\text { predictions and reasons via the } \\
\text { following question: After Bronsted- } \\
\text { Lowry's research on substances (i.e., } \\
\left.\mathrm{CH}_{3} \mathrm{COOH}, \mathrm{CH}_{3} \mathrm{COO}, \mathrm{HCl}, \mathrm{NaOH}\right) \text {, do } \\
\text { you think some substances will donate } \\
\text { their protons to other substances or the } \\
\text { others will accept the donated protons? } \\
\text { Please write your prediction and explain } \\
\text { your reason(s). }\end{array}$ & $\begin{array}{l}\text { Required them to watch the next } \\
\text { section of the animated movies to } \\
\text { observe pairs of conjugate acid and } \\
\text { base; acid-base definitions. Later, } \\
\text { they wrote their observations down on } \\
\text { the worksheet. }\end{array}$ \\
\hline $\begin{array}{l}\text { The Lewis } \\
\text { model } \\
\text { (Task 3) }\end{array}$ & $\begin{array}{l}\text { Asked them to watch the animated } \\
\text { movies on how Lewis determined the } \\
\text { acidity or alkalinity of two substances } \\
\left(\mathrm{BF}_{3} \text { and } \mathrm{NH}_{3}\right) \text {. Later, they were } \\
\text { requested to state their predictions and } \\
\text { reasons via the following question: After } \\
\text { Lewis' research on substances (i.e., } \mathrm{BF}_{3} \\
\left.\text { and } \mathrm{NH}_{3}\right) \text {, do you think a base donates a } \\
\text { pair of electrons to an acid? Do you } \\
\text { think there is any reaction between the } \\
\text { acid and base? Please write your } \\
\text { prediction and explain your reason(s). }\end{array}$ & $\begin{array}{l}\text { Required them to watch the next } \\
\text { section of the animated movies to } \\
\text { observe coordinate covalent bonding; } \\
\text { accepting or donating a pair of } \\
\text { nonbonding electrons; and acid-base } \\
\text { definitions. Later, they put their } \\
\text { observation down on the worksheet. }\end{array}$ \\
\hline
\end{tabular}

\section{Data Analysis}

The related literature generally employs five criteria (sound understanding, partial understanding, partial understanding with specific alternative conception(s), alternative understanding and no understanding) to classify students' responses to open-ended questions or track their conceptual understanding/growth (Abraham et al. 1992; Çalık \& Cobern, 2017; Çalık et al. 2014; Kala, Yaman \& Ayas, 2013). Two of the authors firstly looked over the students' responses to the POE tasks to decide whether these five criteria run well for data analysis procedure. Then, the authors came up with an agreement point excluding 'partial understanding with specific alternative conception' from the criteria since the preliminary review of the data indicated that none of the students' responses to the questions fell into this criterion. Finally, the students' responses to the POE tasks were analyzed through the subsequent four criteria: sound understanding (that includes all components of the validated response), partial understanding (that includes at least one component of the validated responses), alternative understanding (that includes responses, different from scientifically accepted ones) and no understanding (that includes unclear responses or unrelated explanation or left blank) (see Table 2 for a sample categorizing procedure) (Abraham et al. 1992; Çalık \& Cobern, 2017; Er Nas \& Çalık, 2018; Kala et al. 2013). Furthermore, even though the criteria are well-known and widely used in science/chemistry education, someone may think about how to classify an unambiguously and completely wrong answer not corresponding to the scientific one. The related literature suggests 'No understanding' category if it is completely unrelated to the context of the question. However, if it is somewhat relevant with the context of the question, this response may be categorized under 'alternative understanding' category. Hence, it was intended to determine their understanding of each POE stage as well as any difference between their responses to each POE stage (from the 'predict' to the 'explain' stages). Their responses to pre- and post- interviews were firstly transcribed, and then exposed to content analysis. Hence, codes and themes appeared given their similarities and differences (Miles \& Huberman, 1994).

A group of five chemistry educators, who were familiar with the aforementioned criteria and POE strategy, ensured content validity of the POE-AM tasks and appropriateness of the data analysis procedure. The authors separately classified the students' responses to the POE tasks and interview protocols. Any disagreement was resolved through negotiation. Table 2 illustrates a sample categorizing 
procedure of the Arrhenius model (Task 1) for different students. For example; S1 means the first student of the sample.

Table 2

A sample categorizing procedure of the Arrhenius model (Task 1)

\begin{tabular}{|c|c|c|c|c|}
\hline $\begin{array}{c}\text { Level of } \\
\text { understanding }\end{array}$ & Predict & $\begin{array}{l}\text { Reason for } \\
\text { "Predict" }\end{array}$ & Observe & Explain \\
\hline
\end{tabular}

$\mathrm{HCl}$, which is a strong acid, completely dissolves into water by releasing a $\mathrm{H}^{+}$ion. $\mathrm{CH}_{3} \mathrm{COOH}$, which is a weak electrolyte, partially dissociates into water by releasing $\mathrm{H}^{+}$ions.

Therefore, they are viewed as the Arrhenius acids. $\mathrm{SO}_{2}$ and $\mathrm{CO}_{2}$ are excluded since they do not release any $\mathrm{H}^{+}$

Sound

understanding

$\mathrm{Ba}(\mathrm{OH})_{2}, \mathrm{SO}_{2}$ and $\mathrm{CO}_{2}$ are considered as

Partial the Arrhenius

Understanding acids and bases.

$\mathrm{CH}_{3} \mathrm{COOH}$ and $\mathrm{NH}_{3}$ are not considered (S2).
Acids and bases react with each other because $\mathrm{H}^{+}$ and $\mathrm{OH}^{-}$ions water. Acids donate $\mathrm{H}^{+}$ions into water, and bases do $\mathrm{OH}^{-}$ions into water: $\mathrm{H}^{+}+\mathrm{OH}^{-} \rightarrow \mathrm{H}_{2} \mathrm{O}$ (S12) combine to form ion. $\mathrm{NaOH}$ and $\mathrm{Ba}(\mathrm{OH})_{2}$ are seen as the Arrhenius bases since they include $\mathrm{OH}^{-}$ions. Arrhenius cannot explain properly why $\mathrm{NH}_{3}$ in explaining the acidity or alkalinity of certain substances. A neutralization reaction involves the combination of hydrogen and hydroxide ions to form water (S6).

$\mathrm{NH}_{3}$ is not considered as an Arrhenius base because it has no $\mathrm{OH}^{-}$ion. $\mathrm{SO}_{2}$ and $\mathrm{CO}_{2}$ are not considered as Arrhenius acids since they do not have any $\mathrm{H}^{+}$ion. The Arrhenius definition of the acid-base has some limitations in responding the question "Why is $\mathrm{NH}_{3}$ a base?" (S5) is a base. It has limitations
I predicted that every substance was an Arrhenius acid or base. However, I have just noticed that they were not. The substances dissolving into water to produce $\mathrm{H}^{+}$and $\mathrm{OH}^{-}$ions are considered as the Arrhenius acids or bases. Some acids and bases are strong or weak electrolytes. A neutralization reaction between an acid and a base occurs while donating $\mathrm{H}^{+}$ and $\mathrm{OH}^{-}$ions to form water. The Arrhenius definition of the acid-base has some limitations I had not predicted (S10)

I thought that neither $\mathrm{SO}_{2}$ nor $\mathrm{CO}_{2}$ had been an acidic substance; but now I have perceived that they are acidic substances. The Arrhenius model has some pitfalls in adequately explaining some of the acid-base behaviors, e.g., $\mathrm{NH}_{3}$. I viewed $\mathrm{NH}_{3}$ as an Arrhenius base in that I had known $\mathrm{NH}_{3}$ was a base; however, my view of the Arrhenius base was incorrect (S3).

\begin{tabular}{|c|c|c|c|c|}
\hline $\begin{array}{l}\text { Alternative } \\
\text { Understanding }\end{array}$ & - & $\begin{array}{l}\text { Since it } \\
\left(\mathrm{CH}_{3} \mathrm{COOH}\right) \text { is a } \\
\text { weak acid, it } \\
\text { cannot give its } \mathrm{H}^{+} \\
\text {ion. Similarly, it } \\
\left(\mathrm{NH}_{3}\right) \text { is a weak } \\
\text { base and cannot } \\
\text { give its } \mathrm{OH}^{-} \text {ion } \\
(\mathrm{S} 4) .\end{array}$ & - & - \\
\hline $\begin{array}{l}\text { No } \\
\text { Understanding }\end{array}$ & - & $\begin{array}{l}\text { I do not know } \\
\text { (S1). }\end{array}$ & - & - \\
\hline
\end{tabular}




\section{RESULTS AND DISCUSSION}

\section{The Results from the Students' Pre- and Post-Interviews}

This section presents the results from the students' pre- and post-interviews given the first research question of the study. As seen from Table 3, their responses to pre-interviews appeared four codes (H+ ions, $\mathrm{OH}^{-}$ions, Water and No answer) under 'The main part of an acid or a base' theme. Also, the majority of their responses to pre-interviews viewed the main parts of an acid and a base as $\mathrm{H}^{+}$and $\mathrm{OH}^{-}$ ions, respectively.

Table 3

Themes and codes for the students' responses to pre-interviews

\begin{tabular}{|c|c|c|c|}
\hline Themes & Codes & $\mathrm{f}$ & Sample Responses \\
\hline \multirow{4}{*}{$\begin{array}{l}\text { The main part of an acid } \\
\text { or base }\end{array}$} & $\mathrm{H}+\mathrm{ions}$ & 10 & $\begin{array}{l}\text { Let me think. When we investigate chemically, it dissolves and releases } \mathrm{H}^{+} \\
\text {ion... (S6) }\end{array}$ \\
\hline & $\mathrm{OH}^{-}$ions & 10 & $\mathrm{OH}^{-}$. Because it gives $\mathrm{OH}^{-}$ion, when it dissolves (S7). \\
\hline & Water & 1 & $\begin{array}{l}\text { Water. When I put an acid into the water, it becomes solution with an acid or } \\
\text { a base. Namely, I say water (S2). }\end{array}$ \\
\hline & $\begin{array}{l}\text { No } \\
\text { answer }\end{array}$ & 1 & I do not know (S3). \\
\hline
\end{tabular}

f: Frequency

As can be seen from Table 4, after the teaching intervention, most of them depicted the Lewis model as the best acid-base model to address features/behaviors of acids and bases while they viewed the Arrhenius model as the least adequate explanation to imply their features/behaviors. Also, for the least adequate acid-base model, two students stated the Bronsted-Lowry model, and one student implied the Lewis model. Because a student did not remember any model, she was silent for this question.

Table 4

Themes and codes for the students' responses to post-interviews

\begin{tabular}{|c|c|c|c|}
\hline Themes & Codes & $\mathrm{f}$ & Sample Responses \\
\hline \multirow{7}{*}{$\begin{array}{l}\text { The best acid- } \\
\text { base model to } \\
\text { address } \\
\text { features/behaviors } \\
\text { of acids and bases }\end{array}$} & $\begin{array}{l}\text { The Arrhenius } \\
\text { model }\end{array}$ & 1 & $\begin{array}{l}\text { The Arrhenius model is the best theory for me to define the behaviors of } \\
\text { acidic and alkali substances because it is the one I remembered (S2). }\end{array}$ \\
\hline & $\begin{array}{l}\text { The Bronsted- } \\
\text { Lowry Model }\end{array}$ & 3 & $\begin{array}{l}\text { The Bronsted-Lowry model. Because they rebut the acid-base definition } \\
\text { of the Arrhenius model. The acid-base definition of the Bronsted-Lowry } \\
\text { model is more comprehensive than the Arrhenius one (S3). }\end{array}$ \\
\hline & & & $\begin{array}{l}\text { In my opinion, the Lewis model is the best one for defining the } \\
\text { behaviors of acidic and alkali substances. When I think about }\end{array}$ \\
\hline & & & $\begin{array}{l}\text { Arrhenius, he only defines the substances if they include hydrogen or } \\
\text { hydroxide. Bronsted-Lowry defines the acidity or basicity of substances }\end{array}$ \\
\hline & $\begin{array}{l}\text { The Lewis } \\
\text { Model }\end{array}$ & 7 & $\begin{array}{l}\text { that cannot be defined by Arrhenius, but he still has deficiency. In the } \\
\text { end, acids have empty orbitals; bases have extra electrons to donate. To }\end{array}$ \\
\hline & & & $\begin{array}{l}\text { remedy this deficiency, a base gives a pair of electrons to an acid and } \\
\text { they form coordinate covalent bond. Therefore, the most appropriate } \\
\text { model is the Lewis one for me (S6). }\end{array}$ \\
\hline & No answer & 1 & I do not know (S1). \\
\hline \multirow{5}{*}{$\begin{array}{l}\text { The least } \\
\text { adequate } \\
\text { explanation to } \\
\text { imply features / } \\
\text { behaviors of acids } \\
\text { and bases }\end{array}$} & $\begin{array}{l}\text { The Arrhenius } \\
\text { model }\end{array}$ & 8 & $\begin{array}{l}\text { The Arrhenius model. Because it has very simple rationale. It is the } \\
\text { simplest one, but it has some deficiencies. For example; } \mathrm{NH}_{3} \text { includes } \\
\mathrm{H} \text {. If we think any substance including } \mathrm{H} \text { as an acidic substance, we } \\
\text { view } \mathrm{NH}_{3} \text { as an acidic substance, but it is a basic substance (S7). }\end{array}$ \\
\hline & $\begin{array}{l}\text { The Bronsted- } \\
\text { Lowry Model }\end{array}$ & 2 & $\begin{array}{l}\text { The Bronsted-Lowry model. Even though its acid-base definition is } \\
\text { more comprehensive than the Arrhenius one, it has still some } \\
\text { deficiencies in explaining some reactions occurring without proton } \\
\text { transfer (S11). }\end{array}$ \\
\hline & The Lewis & 1 & The Lewis model. Because his definition does not make sense to me \\
\hline & Model & 1 & when I compare it with the Arrhenius and Bronsted-Lowry ones (S5). \\
\hline & No answer & 1 & I do not remember (S1). \\
\hline
\end{tabular}

f: Frequency 


\section{The Results from the Students' Responses to the POE Tasks}

This section displays frequencies of the students' responses to the POE tasks in regard to understanding level. Further, sample responses for the Lewis Model (Task 3) are provided to illustrate their responses to each stage of the POE tasks.

As observed in Table 5, almost all of the students' responses to the 'predict' stage fell into 'partial understanding' category; except for the Bronsted-Lowry model (Task 2) in which two responses were categorized under the 'alternative understanding' category. Whilst the majority of their reasons for the 'predict' stage in Tasks 2-3 were labeled under the 'partial understanding' category, most of them were classified in the 'alternative understanding' category for Task 1 . In the 'observe' stage, the majority of them demonstrated a sound understanding for all tasks. For the 'explain' stage, frequencies of the students' responses categorized under the 'sound understanding' category were 7 for Task 1, 5 for Task 2 and 7 for Task 3, whilst those for the 'partial understanding' category were 5, 7 and 5 respectively.

Table 5

Frequencies of the students' responses to the POE tasks in regard to understanding level

\begin{tabular}{|c|c|c|c|c|c|}
\hline $\begin{array}{l}\text { Stages of } \\
\text { the POE }\end{array}$ & $\begin{array}{l}\text { Understanding } \\
\text { Levels }\end{array}$ & Task 1 & Task 2 & Task 3 & Sample responses for the Lewis Model (Task 3) \\
\hline \multirow{4}{*}{ Predict } & $\begin{array}{l}\text { Sound } \\
\text { Understanding }\end{array}$ & - & - & - & - \\
\hline & $\begin{array}{l}\text { Partial } \\
\text { Understanding }\end{array}$ & 12 & 10 & 12 & $\begin{array}{l}\text { The bases will donate a pair of electron to the acids, which } \\
\text { have empty orbitals. Besides, when the base donates a pair } \\
\text { of electron, it will be at a steady state (S6). }\end{array}$ \\
\hline & $\begin{array}{l}\text { Alternative } \\
\text { Understanding }\end{array}$ & - & 2 & - & - \\
\hline & No Understanding & - & - & - & - \\
\hline \multirow{4}{*}{$\begin{array}{l}\text { Reason for } \\
\text { 'predict' }\end{array}$} & $\begin{array}{l}\text { Sound } \\
\text { Understanding }\end{array}$ & 1 & 1 & 4 & $\begin{array}{l}\text { When the base donates its electron, the acids fill its empty } \\
\text { outer orbital. Thus, the base will be at a steady state (S6). }\end{array}$ \\
\hline & $\begin{array}{l}\text { Partial } \\
\text { Understanding }\end{array}$ & 3 & 10 & 8 & $\begin{array}{l}\text { To me, there will be a reaction. The base will donate a pair } \\
\text { of electron to the acid ( } \mathrm{S} 2) \text {. }\end{array}$ \\
\hline & $\begin{array}{l}\text { Alternative } \\
\text { Understanding }\end{array}$ & 7 & 1 & - & - \\
\hline & No Understanding & 1 & - & - & - \\
\hline \multirow{4}{*}{ Observe } & $\begin{array}{l}\text { Sound } \\
\text { Understanding }\end{array}$ & 8 & 7 & 9 & $\begin{array}{l}\text { The Lewis model also defines any acid or base suggested } \\
\text { by the Bronsted-Lowry and Arrhenius models. In the acid- } \\
\text { base definition of the Lewis model, the bases donate a pair } \\
\text { of electron to the acids; then the acid and base yield a } \\
\text { coordinate covalent bond sharing this electron pair (S2). }\end{array}$ \\
\hline & $\begin{array}{l}\text { Partial } \\
\text { Understanding }\end{array}$ & 4 & 5 & 3 & $\begin{array}{l}\text { While an acid is an electron pair acceptor, a base is an } \\
\text { electron-pair donor. A reaction between an acid and a base } \\
\text { of the Lewis model results in a covalent bond (S6). }\end{array}$ \\
\hline & $\begin{array}{l}\text { Alternative } \\
\text { Understanding }\end{array}$ & - & - & - & - \\
\hline & No Understanding & - & - & - & - \\
\hline \multirow{4}{*}{ Explain } & $\begin{array}{l}\text { Sound } \\
\text { Understanding }\end{array}$ & 7 & 5 & 7 & $\begin{array}{l}\text { In my prediction, I stated that the base would donate a pair } \\
\text { of electron. It happened like this. According to the acid- } \\
\text { base definition of the Lewis model, a substance donating a } \\
\text { pair of electron is a base. If it accepts a pair of electron, it } \\
\text { is an acid. After a reaction between an acid and a base of } \\
\text { the Lewis model, a coordinate covalent bond emerges (S2). }\end{array}$ \\
\hline & $\begin{array}{l}\text { Partial } \\
\text { Understanding }\end{array}$ & 5 & 7 & 5 & $\begin{array}{l}\text { The bases donate a pair of electron; the acids accept the } \\
\text { electron donated. Therefore, the bases become at a steady } \\
\text { state with minimum energy (S6). }\end{array}$ \\
\hline & $\begin{array}{l}\text { Alternative } \\
\text { Understanding }\end{array}$ & - & - & - & - \\
\hline & No Understanding & - & - & - & - \\
\hline
\end{tabular}

Task 1: The Arrhenius model; Task 2: The Bronsted-Lowry model; Task 3: The Lewis model 
As seen in Table 6, the sample student's responses to Task 1 (the Arrhenius model) were labeled under 'partial understanding' through the POE stages. The eleventh student (S11) tended to confirm his prediction through the POE strategy.

Table 6

The eleventh student's (S11) responses as a sample quotation through the POE strategy for Task 1

\begin{tabular}{|c|c|}
\hline Stages of the POE & The student's responses \\
\hline Predict & $\begin{array}{l}\mathrm{NaOH}, \mathrm{Ba}(\mathrm{OH})_{2}, \mathrm{HCl}, \mathrm{CH}_{3} \mathrm{COOH} \text { are considered as Arrhenius } \\
\text { acids and bases. }\end{array}$ \\
\hline Reason for 'predict' & $\begin{array}{l}\text { Because these are acids and bases that include } \mathrm{H}^{+} \text {and } \mathrm{OH}^{-} \text {ions. } \\
\mathrm{NaOH} \text { and } \mathrm{Ba}(\mathrm{OH})_{2} \text { include } \mathrm{OH}^{-} \text {ions; hence, they are seen as the }\end{array}$ \\
\hline Observe & $\begin{array}{l}\text { Arrhenius bases. } \mathrm{HCl} \text { and } \mathrm{CH}_{3} \mathrm{COOH} \text { are viewed as the Arrhenius } \\
\text { acids since they include } \mathrm{H}^{+} \text {ions. }\end{array}$ \\
\hline Explain & $\begin{array}{l}\text { There was no difference between my prediction and observation. I } \\
\text { predicted that } \mathrm{NaOH}, \mathrm{Ba}(\mathrm{OH})_{2}, \mathrm{HCl}, \mathrm{CH}_{3} \mathrm{COOH} \text { were considered } \\
\text { as the Arrhenius acids and bases since they included } \mathrm{H}^{+} \text {and } \mathrm{OH}^{-} \\
\text {ions. I observed what I predicted. }\end{array}$ \\
\hline
\end{tabular}

As seen in Table 7, the sample student's responses to Task 2 (the Bronsted-Lowry model) included alternative understanding for the 'predict and its reason' stages and sound understanding for the 'observe and explain' stages. In this example, the student tended to see negative charged ions as the BronstedLowry bases. That is, she viewed the negative charges as indicators of the Bronsted-Lowry acids-bases. Further, the student's response in the 'predict' stage did not refer to the proton transfer and the concept of the conjugate acid-base. After the 'observe' stage, she realized that the Bronsted-Lowry model extended the acid-base definition depicted by the Arrhenius model and explained the acidity or alkalinity of the substances that Arrhenius model was unable to depict. In the 'explain', she clearly addressed the Bronsted-Lowry model explaining the acidity or alkalinity of any substance through proton transfer.

Table 7

The eighth student's (S8) responses as a sample quotation through the POE strategy for Task 2

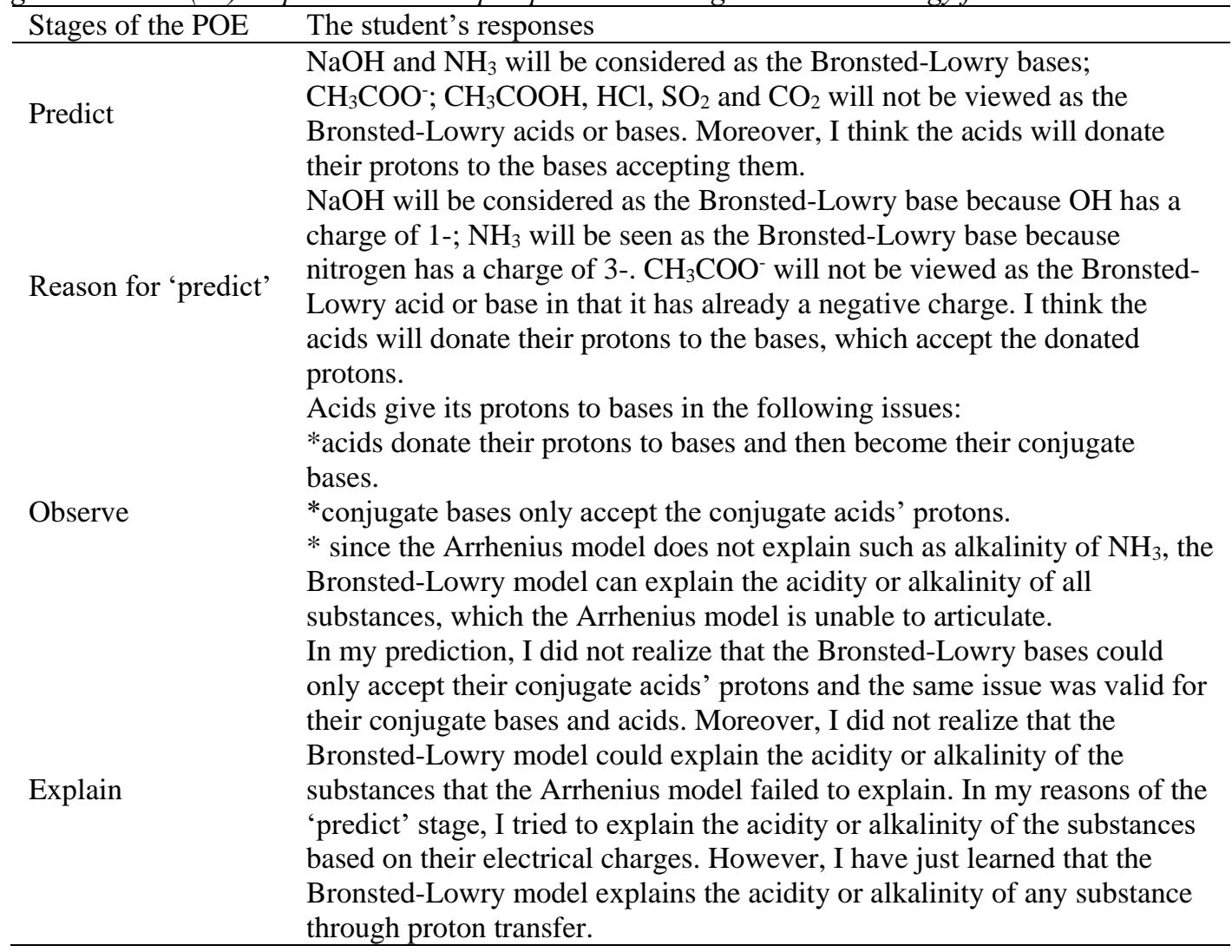


As observed in Table 8, the student responses to the 'predict and its reason' stages fell into 'partial understanding' level. Also, his responses to the 'observe and explain' stages were classified under 'sound understanding' level. This proves that the 'observe and explain' stages of the POE-AM improved his responses from partial understanding to sound understanding.

Table 8

The twelfth student's (S12) responses as a sample student response matching the POE strategy with the POE-AM (Task 3)

\begin{tabular}{|c|c|c|}
\hline Stages of the POE & The POE-AM (Task 3) & The student's responses \\
\hline Predict & $\begin{array}{l}\text { Asked them to watch the animated } \\
\text { movies on how Lewis determined the }\end{array}$ & $\begin{array}{l}\text { I think the bases will donate some pairs of } \\
\text { electrons to the acids. }\end{array}$ \\
\hline Reason for 'predict' & $\begin{array}{l}\text { acidity or alkalinity of two substances } \\
\left(\mathrm{BF}_{3} \text { and } \mathrm{NH}_{3}\right) \text {. Later, they were } \\
\text { requested to state their predictions and } \\
\text { reasons via the following question: Do } \\
\text { you think a base donates a pair of } \\
\text { electrons to an acid? Do you think there } \\
\text { is any reaction between the acid and } \\
\text { base? }\end{array}$ & $\begin{array}{l}\text { Because the bases donate some pairs of } \\
\text { electrons to the acids, the acids will fill its } \\
\text { empty outer orbitals. }\end{array}$ \\
\hline Observe & $\begin{array}{l}\text { Required them to watch the next section } \\
\text { of the animated movies to observe } \\
\text { coordinate covalent bonding; accepting } \\
\text { or donating a pair of nonbonding } \\
\text { electron pairs; and acid-base definitions. } \\
\text { Later, they put their observation down } \\
\text { on the student worksheet. }\end{array}$ & $\begin{array}{l}\text { *The Lewis model suggests another acid-base } \\
\text { definition, which is different from those of the } \\
\text { Bronsted-Lowry and Arrhenius models. } \\
\text { *In the acid-base definition of the Lewis } \\
\text { model, bases donate a pair of nonbonding } \\
\text { electrons to acids; hence, they share a pair of } \\
\text { electrons to form a coordinate covalent bond. }\end{array}$ \\
\hline Explain & $\begin{array}{l}\text { Asked to respond the following } \\
\text { questions: Is there any discrepancy } \\
\text { between your prediction and } \\
\text { observation? Please state your reason(s). }\end{array}$ & $\begin{array}{l}\text { In my prediction, I forgot to clearly handle the } \\
\text { electron-pair donor (the Lewis base) and } \\
\text { electron pair acceptor (the Lewis acid) while } \\
\text { sharing pairs of electrons. }\end{array}$ \\
\hline
\end{tabular}

\section{CONCLUSIONS}

The main purpose of this study was to facilitate grade 11 students' conceptual understanding of the acidbase models using POE-AM tasks. The results showed that the majority of the students thought the main parts of an acid and a base as $\mathrm{H}^{+}$or $\mathrm{OH}^{-}$ions respectively before the teaching intervention. This may result from grade 8 science curriculum only referring to the Arrhenius model (Sheppard, 2006). As a matter of the fact, after the teaching intervention, the majority of them viewed the Arrhenius model as the least adequate explanation to imply the features/behaviors of the acids and bases. Given a comparison of three acid-base models, they tended to find the Arrhenius model primitive. Because they were firstly confronted with the Arrhenius model in grade 8 science curriculum, they seem to have been more familiar with the Arrhenius model (Kousathana, Demerouti \& Tsaparlis, 2005). Further, this knowledge claim is consistent with Tümay's (2006) finding stating that even pre-service chemistry teachers were more familiar with the Arrhenius model as compared with the Bronsted-Lowry and Lewis models. Indeed, despite this familiarity, the students under investigation still possessed difficulties in identifying the substances as acids and bases in the 'predict' stage of the POE strategy (see Table 5). This may stem from a limited number of the acid-base samples used in grade 8 . To overcome their deficiencies of the acid-base models, Hawkes (1992) suggests that the Bronsted-Lowry model, which defines the acids and bases throughout proton transfer, should be firstly taught. He also claims that the Bronsted-Lowry model, which is more student-friendly than the Arrhenius model, does not result in any misunderstanding of the acids and bases. Similarly, Paik (2015) offers that a non-sequential learning, which gives an oppurtunity for students to compare the fundamental acid-base models with one another, 
will be more useful for teaching the acid-base chemistry. In contrast, Artdej, Ratanaroutai, Coll and Thongpanchang (2011) suggest to chronologically instruct the acid-base models and integrate this chronological order into the textbooks. Teaching the acid-base models with or without the chronological order has still been challenging to the current literature. However, the present study found that the students' views of the historical order of the acid-base models resulted in putting forward the Lewis model. That is, the current study, which historically argued the needs of three acid-base models, might lead the students to view the Lewis model as the best one. In a similar vein, the students might pay more attention to the historical order of three acid-base models. This seems to have triggered their understanding of the acid-base models. In fact, an improvement in their conceptions/views of the acidbase models seems to have refuted Hawkes' (1992) point of view. Even though Zoller (1990) and Tarhan and Acar Sesen $(2008,2012)$ reported that many students had difficulties in understanding the Lewis model involving such complex concepts as acidity and basicity, Task 3 in the current teaching intervention helped them scientifically comprehend acidity, basicity, and electron pair-transfer from a base to an acid.

Given the students' deficiencies of the acid-base models (Artdej et al., 2011; Carr, 1984; Cartrette \& Mayo, 2011; Cooper, Kouyoumdjian \& Underwood, 2016; Dreshler \& Schmith, 2005a, b; Dreschler \& Van Driel, 2008; Tarhan \& Sesen, 2012; Zoller, 1990), the POE-AM positively improved their conceptual understanding from the 'predict' stage to the 'explain' one and remedied any deficiency identified in pre-interviews and/or the 'predict' stage of the POE strategy. However, minority of the students only attempted to clarify their predictions throughout the POE tasks. That is, they tended to observe what they wanted to see (Liew, 1995; White \& Gunstone, 1992). This may come from poor observational skills (Liew, 1995). An increase in scientific responses from Task 1 to Task 3 means that the POE-AM enabled them to learn how to implement the POE strategy. This may be interpreted as an improvement in observational and inferential skills. Furthermore, any cognitive conflict from the 'predict' stage to the 'explain' one of the POE strategy seems to have given an opportunity for them to rebuild their understanding. Such a procedure may increase learning possibility and capacity via the POE tasks (Kearney, 2004; Kearney \& Treagust, 2001; Kearney et al, 2001; Liew \& Treagust, 1998). Phrased differently, because the POE-AM combined visual-pictorial (e.g., student worksheets and animated movie characters) and auditory-verbal (i.e., characters' voices) channels (Mayer, 2002), they seem to have promoted their conceptual understanding of the acid-base models.

Given frequencies of the student responses categorized under the 'sound understanding' category in the 'observe' and 'explain' stages of the POE strategy, the students were good at depicting their observations rather than their explanations. This means that the students seem to have paid more attention to their observations posed by animated movie and/or student worksheets and/or inquiry-based learning (Çalık, Kolomuç \& Karagölge, 2010; Ültay \& Çalık, 2016). In other words, this may stem from a lack of argumentation skills transferring observations to explanations/inferences (Bağ \& Çalık, 2017; Ültay \& Çalık, 2016). Inserting an explicit 'discuss' stage into the POE strategy might afford them to yield a dialogic link between the 'observe' and 'explain' stages (Çalık \& Cobern, 2017; Kearney, 2004).

The current study suggests that chemistry teachers should integrate the POE-AM into their classes and/or other chemistry topics to effectively promote student learning. Further, a historical order of the acidbase models ought to be handled with their differences and discrepancies. Future study may be undertaken to test the extent to which the explicit or implicit use of the historical order of the acid-base models influences their conceptual understanding. Moreover, a balance between macroscopic and submicroscopic levels and between theoretical (i.e., acid-base models) and practical knowledge (e.g., POE and animated videos) (named dual-situated learning) (Bağ \& Çalık, 2017; Bakırcı, Çalık \& Çepni, 2017; Çalık, Ayas \& Coll, 2009) calls for further studies concentrating on the interlinks amongst the macroscopic, sub-microscopic and symbolic levels. To accomplish better conceptual understanding, future studies should initially probe students' pre-existing knowledge/alternative conceptions and then involve them into a teaching intervention or guide materials (Çalık, Ayas \& Coll, 2009; Karslı \& Çalık, 2012). Furthermore, students' difficulties of observation and explanation/inference necessities to clearly 
integrate the nature of science into science/chemistry classes, which may be of interest in future studies (Bakırc1 et al. 2017).

\section{Limitations}

The current study has three limitations. Since this study was conducted with a small sample size, someone may consider its applicability as the first limitation. Secondly, the present study only handled the Arrhenius, Bronsted-Lowry and Lewis models, and omitted the others. Because the POE strategy implicitly and explicitly use 'discussion' issue, the related literature contains its derivered versions (i.e., PEOE and PDEODE). Even though the current study integrated "discussion" issue into the POE-AM tasks, it preferred using its original version (i.e., POE) to its derived ones (i.e., PEOE and PDEODE). This may be seen as another limitation of the study.

\section{Acknowledgement}

This study includes a part of the first author's PhD Thesis.

\section{REFERENCES}

Abdullah, A., \& Scaife, J., (1997). Using interviews to assess children's understanding of science concepts. School Science Review, 78, 285, 79-84.

Abraham, M. R., Grzybowski, E. B., Renner, J. W., \& Marek, E. A. (1992). Understandings and misunderstandings of eighth graders of five chemistry concepts found in textbooks. Journal of Research in Science Teaching, $29,105-120$.

Artdej, R., Ratanaroutai, T., Coll, R. K., \& Thongpanchang, T. (2011). Thai grade 11 students' alternative conceptions for acid-base chemistry. Research in Science \& Technological Education, 28(2), 167-183.

Bağ, H. \& Çalık, M. (2017). A thematic review of argumentation studies at the K-8 level. Education and Science, 42(190), 281-303.

Bahar, M., \& Tongaç, E. (2009). The effect of teaching approaches on the pattern of pupils' cognitive structure: Some evidence from the field. The Asia Pacific Education Researcher, 18(1), 21-45.

Bakırcı, H., Çalık, M. \& Çepni, S. (2017). The effect of the common knowledge construction model-oriented education on sixth grade pupils' views on the nature of science. Journal of Baltic Science Education, 16(1), 43-55.

Barak, M., Ashkar, T., \& Dori, Y. J. (2011). Learning science via animated movies: Its effect on students' thinking and motivation. Computers \& Education, 56(3), 839-846.

Çalık, M., Ayas, A. \& Coll, R. K. (2007). Enhancing pre-service primary teachers' conceptual understanding of solution chemistry with conceptual change text. International Journal of Science and Mathematics Education, 5(1), 1-28.

Çalık, M., Ayas, A. \& Coll, R.K. (2009). Investigating the effectiveness of an analogy activity in improving students' conceptual change for solution chemistry concepts. International Journal of Science and Mathematics Education, 7(4), 651-676.

Çalık, M., Kolomuç, A. \& Karagölge, Z. (2010). The effect of conceptual change pedagogy on students' conceptions of rate of reaction. Journal of Science Education and Technology, 19, 422-433.

Çalık, M., \& Cobern, W. W. (2017). A cross-cultural study of CKCM efficacy in an undergraduate chemistry classroom. Chemistry Education Research and Practice, 18, 691-730.

Çalik, M., Ebenezer, J., Özsevgeç, T., Küçük, Z. \& Artun, H. (2015). Improving science student teachers' selfperceptions of fluency with innovative technologies and scientific inquiry abilities. Journal of Science Education and Technology, 24(4), 448-460.

Çalik, M., Özsevgeç, T., Ebenezer, J., Artun, H. \& Küçük, Z. (2014). Effects of 'environmental chemistry' elective course via technology embedded scientific inquiry model on some variables. Journal of Science Education and Technology, 23(3), 412-430.

Carr, M. (1984). Model confusion in chemistry. Research in Science Education, 14, 97-103. 
Cartrette, D. P. \& Mayo, P.M (2011). Students' understanding of acids/bases in organic chemistry contexts. Chemistry Education Research and Practice, 12(1), 29-39.

Cooper, M., Kouyoumdjian, H. \& Underwood, S. U. (2016). Investigating students' reasoning about acid-base reactions. Journal of Chemical Education, 93, 1703-1713.

Coştu, B., Ayas, A., \& Niaz, M. (2012). Investigating the effectiveness of a POE-based teaching activity on students' understanding of condensation. Instructional Science, 40,47-67.

Creswell, J. W., \& Plano Clark, V. L. (2011). Designing and conducting mixed methods research. Thousand Oaks, CA: Sage Publications, Inc.

Drechsler, M., \& Schmidt, H.-J. (2005a). Upper secondary school students' understanding of models used in chemistry to define acids and bases. Science Education International, 16, 39-54.

Drechsler, M., \& Schmidt, H.-J. (2005b). Textbooks' and teachers' understanding of acid-base models used in chemistry teaching. Chemistry Education: Research and Practice, 6, 19-35.

Drechsler, M., \& Van Driel, J. (2008). Experienced teachers' pedagogical content knowledge of teaching acidbase chemistry. Research in Science Education, 38(5), 611-631.

Er Nas, S., Calik, M. \& Cepni, S. (2012). Effect of different conceptual change pedagogies embedded within 5E model on grade 6 students' alternative conceptions of 'heat transfer.' Energy, Education, Science and Technology Part B Social and Educational Studies, 4(1), 177-186.

Er Nas, S., \& Çalık, M. (2018). A cross-age study of science student teachers' conceptual understanding of soil erosion. Problems of Education in the 21st century, 76(5), 601-619.

Hawkes, S.J. (1992). Arrhenius confuses students. Journal of Chemical Education, 69, 542-543.

Justi R.S, \& Gilbert, J.K. (2002). Modelling, teachers' view on the nature of modeling, and implications for the education of modelers, International Journal of Science Education, 24(4), 369-387.

Kala, N., Yaman, F. \& Ayas, A. (2013). The effectiveness of predict-observe-explain technique in probing students' understanding about acid-base chemistry: A case for the concepts of $\mathrm{pH}$, pOH and strenght. International Journal of Science and Mathematics Education, 11(3), 555-574.

Karslı, F. \& Çalık, M. (2012). Can freshman science student teachers' alternative conceptions of 'electrochemical cells' be fully diminished? Asian Journal of Chemistry, 24(2), 485- 491.

Kearney, M. (2004). Classroom use of multimedia-supported predict-observe-explain tasks in a social constructivist learning environment. Research in Science Education, 34, 427-453.

Kearney, M., \& Treagust, D.F. (2001). Constructivism as a referent in the design and development of a computer program which uses interactive digital video to enhance learning in physics. Australian Journal of Educational Technology, 17(1), 64-79.

Kearney, M., Treagust, D., Shelley Y., \& Zadnik M. (2001). Student and teacher perception of the use of multimedia supported predict- observe- explain task to probe understanding. Research in Science Teaching, 31, 539- 615.

Kiryak, Z. \& Çalik, M. (2018). Improving grade 7 students' conceptual understanding of water pollution via common knowledge construction model. International Journal of Science and Mathematics Education, 16(6), 1025-1046.

Kousathana M., Demerouti M., \& Tsaparlis G. (2005). Instructional misconceptions in acid base equilibria: An analysis from a history and philosophy of science perspective. Science and Education, 14, 173-193.

Liew, C. W. (1995). A predict-observe-explain teaching sequence for learning about students' understanding of heat. Australian Science Teachers Journal, 41(1), 68- 72.

Liew, C. W., \& Treagust, D F. (1998). The effectiveness of predict-observe-explain tasks in diagnosing students' understanding of science and in identifying their levels of achievement. Paper presented at the Annual Meeting of the American Educational Research Association, April 13-17, San Diago.

Mayer, R. E. (2002). Cognitive theory and the design of multimedia instruction: An example of the two-way street between cognition and instruction. In D. F. Halpern, \& M. D. Hakel (Eds.), Applying the science of learning to university teaching and beyond (pp. 55-72). San Francisco: Jossey-Bass.

Merriam, S. B. (2009). Qualitative research: A guide to design and implementation. San Francisco: Jossey-Bass.

Miles, M. B., \& Huberman, A. M. (1994). Qualitative data analysis: A sourcebook of new methods (2nd ed.). Thousand Oaks, CA: Sage.

MONE (Ministry of National Education) (2013a). Science and technology curriculum for grades 5-8. Ankara: MEB Publishing.

MONE (Ministry of National Education) (2013b). Chemistry curriculum for grades 9-12. Ankara: MEB Publishing.

Novak, J. D., \& Gowin, D. B. (1984). Learning how to learn. New York, NY: Cambridge University Press.

Osborne R.J., \& Cosgrove M.M. (1983). Children's conceptions of the changes of states of water. Journal of Research in Science Teaching, 20, 825-838.

Patton, M. Q. (2002). Qualitative evaluation and research methods (3rd ed.). Thousand Oaks, CA: Sage Publications, Inc. 
Tarhan, L., \& Acar-Sesen, B. (2008). An application of jigsaw cooperative learning for understanding "acid-base theories." Paper presented at the XIII. IOSTE, Izmir, Turkey.

Tarhan, L., \& Acar-Sesen, B. (2012). Jigsaw cooperative learning: Acid-base theories. Chemistry Education Research and Practice, 13(3), 307-313.

Ültay, N. \& Çalık, M. (2016). A comparison of different teaching designs of 'acids and bases' subject. Eurasia Journal of Mathematics, Science \& Technology Education, 12(1), 55-86.

White, R.T., \& Gunstone, R.F. (1992). Probing understanding. Hong Kong: Graphicraft ltd.

Zoller, U. (1990). Students' misunderstandings and misconceptions in college freshman chemistry (general and organic). Journal of Research in Science Teaching, 27(10), 1053-1065. 


\section{TÜRKÇE GENIȘLETILMIŞ ÖZET}

$\mathrm{Bu}$ çalışma, 11. sınıf öğrencilerinin temel asit-baz modelleriyle ilgili kavramsal anlamalarını TahminGözlem-Açıklama temelli animasyon filmleriyle (TGA-AF) artırmayı amaçlamaktadır.

Bu çalışmada şu araştırma sorularına cevap aranmıştır:

(1) 11. sınıf öğrencilerinin uygulama öncesi ve sonrası temel asit-baz modelleriyle ilgili anlama seviyeleri nasıldır?

(2) 11. sınıf öğrencilerinin uygulama sonrasında anlama seviyeleri nasıl değişmiştir?

Bu çalışmaya alt, orta ve üst başarı seviyelerinden seçilen toplam 12 onbirinci sınıf öğrencisi katılmıştır. Veri toplamak için öğrencilerin TGA çalışma yapraklarındaki cevapları ve yarı yapılandırılmış mülakatlar kullanılmıştır. Yarı yapılandırılmış mülakatlar müdahale öncesi ve sonrası olarak uygulanırken, TGA çalışma yaprakları ise müdahale süreci içerisinde kulanılmıştır. Çalışmada karma yöntemin gömülü (embedded) deseni kullanılmıştır. Tahmin-Gözlem-Açıklama temelli animasyon filmleri (TGA-AF) mevcut öğretim programının bir parçası olarak öğretim sürecine dahil edilmiştir. Bu çalışmada, Arrhenius, Bronsted-Lowry ve Lewis asit-baz modelleriyle ilgili toplamda üç etkinlik kullanılmış olup her bir etkinlik iki ders saati içerisinde gerçekleştirilmiştir.

Çalışmada kullanılan TGA-AF'nin hazırlanmasında, öncelikle her bir asit-baz modeline yönelik hikaye oluşturulmuş ve sonrasında da TGA yönteminin içerisine yerleştirilmiştir. Öğrencilerin bireysel olarak çalışmasının planlandığı TGA- AF etkinliklerinin başında ilgili çalışma kağıtları dağıtılmıştır. Böylece, TGA-AF etkinlikleri esnasında, öğrenciler öncelikle hikayenin genel kısmını izlemiş ve sonrasında da hikayenin geri kalan kısmında ne olacağını tahmin etmişlerdir. Öğrenciler tahminlerini gerekçeleriyle birlikte açıkladıktan ve çalışma kağıdına yazdıktan sonra ise hikayenin geri kalan kısmını izlemiş ve bununla ilgili gözlem notlarını çalışma kağıtlarına yazmışlardır. Öğrencilerin tahminleri ve gözlemleri arasında herhangi bir farklılık olup olmadığ bir etkinlikten sonra öğrencilerin çalışma kağıtları toplanmış ve analiz edilmiştir.

Yarı yapılandırılmış mülakatların analizinde, öğrenci mülakatları transkript edilmiş ve içerik analizine tabii tutulmuştur. Böylece, açık kodlama yapılarak, benzerlik ve farklılıklara göre kategori ve temalar oluşturulmuştur. Öğrencilerin TGA-AF etkinliklerine verdikleri cevaplar ise tam anlama, kısmi anlama, alternatif anlama ve anlamama kategorilerine göre analiz edilmiştir. Tam anlama kategorisi, bilimsel olarak geçerli olan cevabın bütün bileşenlerini içerirken, kısmi anlama kategorisi bilimsel olarak geçerli olan cevabın en az bir bileşenini içermektedir. Alternatif anlama kategorisi, bilimsel olarak kabul edilenden farklı bilgileri ele alırken, anlamama kategorisi ise ilgisiz ve/veya boş bırakılan cevapları içermektedir.

TGA stratejisine ve veri analizi kategorilerine aşina olan 5 kimya eğitimcisi TGA-AF etkinliklerinin kapsam geçerliğini ve veri analiz sürecinin uygunluğunu kontrol etmiş ve doğrulamıştır. Aynı zamanda, araştırmacılar öğrencilerin TGA etkinliklerine ve mülakat protokollerine verdikleri cevapları ayrı ayrı sınıflandırılmıştır. Araştırmacılar arasındaki herhangi bir farklılık veya uyuşmazlık müzakereyle çözülmüş̧ür.

Çalışmanın ilk araştırma sorusuna cevap bulabilmek için öğrencilerin ön ve son mülakat bulguları incelenmiştir. Bu incelemede, uygulama öncesinde öğrencilerin çoğunluğunun (10 öğrenci) bir asidin temel parçasının $\mathrm{H}^{+}$iyonu olduğunu ve bir bazın temel parçasının ise $\mathrm{OH}^{-}$iyonu olduğunu düşündükleri ortaya çıkmıştır (Bakınız Tablo 3). Ayrıca, uygulama sonunda öğrencilerin çoğunluğu (7 öğrenci), temel asit-baz modelleri arasında asit-baz özelliklerini ve davranışlarını en iyi açılayan model olarak Lewis 
asit-baz modelini ifade etmiştir (Bakınız Tablo 4). Buna karşın, öğrencilerin çoğunluğu (8 öğrenci) asitbaz modelleri arasında Arrhenius asit-baz tanımını yeterliği en az olan model olarak belirtmişlerdir.

Çalışmanın ikinci araştırma sorusuna cevap bulabilmek için öğrencilerin Arrhenius, Bronsted-Lowry ve Lewis asit-baz modelleriyle ilgili TGA-AF etkinliklerine verdiği cevaplar irdelenmiştir. Bu incelemede, tahmin aşamasında öğrencilerin çoğunluğunun verdiği cevapların kısmi anlama kategorisinde olduğu ortaya çıkmıştır. Bu bağlamda, öğrencilerin tamamının (12 öğrenci) Arhenius ve Lewis asit-baz modellerinde, çoğunluğunun ise (10 öğrenci) Bronsted-Lowry asit-baz modelinde kısmi anlama kategorisinde cevaplar verdiği görülmektedir. Öğrenci tahminlerinin sebepleri incelendiğinde ise, Bronsted-Lowry ve Lewis asit-baz modelleriyle ilgili etkinliklerde öğrencilerin çoğunluğunun kısmi anlama (Bronsted-Lowry modelinde 10 ve Lewis asit-baz modelinde 8 öğrenci) kategorisinde cevaplar verirken, Arrhenius asit-baz modeliyle ilgili etkinlikde ise verdikleri cevapların alternatif anlama (Arrhenius asit-baz modeli için 7 öğrenci) kategorisinde olduğu ortaya çıkmıştır. Öğrencilerin Arrhenius, Bronsted-Lowry ve Lewis asit-baz modelleriyle ilgili etkinliklerin gözlem aşamasında verdiği cevaplardan tam anlama kategorisinde olanların frekansları sırasıyla 8,7 ve 9 tespit edilirken, açıklama aşamasında ise tam anlama kategorisindeki cevapların frekansının aynı asit-baz modeli sırası için 7, 5 ve 7 olduğu görülmektedir (Bakınız Tablo 5).

Çalışmada ortaya çıkan sonuçlar göz önünde bulundurulduğunda, kimya öğretmenlerinin TGA-AF etkinliklerini kendi sınıflarına ya da başka kimya konularına uyarlamaları önerilmektedir. Ayrıca, asitbaz modellerinin öğretiminde tarihsel sırayla birlikte modellerin benzerlik ve farklılıklarının vurgulanmasının kavramsal öğrenmeyi kolaylaştıracağı düşünülmektedir. 